\title{
Evaluation of Multiple Herbicides for Control of Sponge Plant (Limnobium laevigatum)
}

\author{
Ben E. Willis*, Mark A. Heilman, West M. Bishop, Scott W. Shuler \\ SePRO Research and Technology Campus, SePRO Corporation, Whitakers, USA \\ Email: *ben.willis@sepro.com
}

How to cite this paper: Willis, B.E., Heilman, M.A., Bishop, W.M. and Shuler, S.W. (2018) Evaluation of Multiple Herbicides for Control of Sponge Plant (Limnobium laevigatum). Journal of Geoscience and Environment Protection, 6, 56-64. https://doi.org/10.4236/gep.2018.66004

Received: April 17, 2018

Accepted: June 18, 2018

Published: June 21, 2018

Copyright $\odot 2018$ by authors and Scientific Research Publishing Inc. This work is licensed under the Creative Commons Attribution International License (CC BY 4.0).

http://creativecommons.org/licenses/by/4.0/

\begin{abstract}
Sponge plant is an emerging threat that has spread throughout California including the Sacramento-San Joaquin Delta, which is an important water resource for agriculture as well as critical habitat for a variety of threatened and endangered species. More data are needed on effective control methods for this spreading invader, as current management practices are not preventing proliferation. The overall objectives of this research were to evaluate imazamox, penoxsulam, topramezone, florpyrauxifen-benzyl, and carfentrazone-ethyl for control of sponge plant using three testing scales, as well as compare image analysis software to traditional biomass response for measuring herbicide performance. Overall, $280 \mathrm{~g}$ imazamox $\mathrm{ha}^{-1}$ (with one-percent methylated seed oil surfactant) was found as a potent solution for all different growth stages of sponge plant, and $70 \mathrm{~g}$ penoxsulam ha ${ }^{-1}$ as an alternative for control of sponge plant in the seedling and rosette growth stage. The image analysis software yielded similar measurement of herbicide effects as traditional biomass measure. Mesocosm testing indicated imazamox treatment sites should be inspected at four week intervals to identify plants missed by prior applications. This research provides water resource managers critical information for identification of an aquatic invasive species, and selecting an effective rapid management program.
\end{abstract}

\section{Keywords}

Imazamox, Clearcast, Penoxsulam, Galleon, Sacramento-San Joaquin Delta, Canopeo

\section{Introduction}

New invasive weeds are constantly introduced to waterways, which can lead to major ecological changes and economic impact if not appropriately managed. 
One such aquatic weed of growing prevalence in California is sponge plant [Limnobium laevigatum (Humboldt and Bonpland ex Willdenow) Heine]. This new arrival to the United States is native to South America, Central America, and the Caribbean [1] [2]. This monocot has now been found throughout California, though was first documented on 1996 in an East Bay hills pond system [3]. The initial population was eradicated, however in 2003, new populations appeared in a few ponds inside the cities of Redding and Arcata [4]. In 2007, this plant was found a couple of miles along the San Joaquin River, and eventually spread to the Sacramento-San Joaquin Delta in 2008. The Sacramento-San Joaquin Delta is a critical water resource in California, covering 61,619 acres, and an area of concern for widespread distribution. Ecologically, the delta is habitat for several endangered and threatened species including the delta smelt (Hypomesus transpacificus McAllister), chinook salmon (Oncorhynchus tshawytscha Walbaum in Artedi), and North American green sturgeon (Acipenser medirostris Ayres) [5]. The delta also serves as a source of irrigation water for over 200,000 hectares of agricultural land, assists in water conveyance as part of the Central Valley Project and State Water Projects of California, allows navigation for commercial shipping, and has extensive recreational uses [5].

Sponge plant can be difficult to identify as possesses three distinct growth patterns including: 1) a seedling stage mimicking duckweed (Lemna sp. and Landoltia sp.), 2) a rosette stage that looks similar to immature fragrant water lily (Nymphaea odorata Aiton), and 3) a stalked emergent stage often mistaken as waterhyacinth [Eichhornia crassipes (Mart.) Solms] [4]. A key identification attribute of sponge plant is aerenchyma located on the underside of the leaf. Aerenchyma of seedling and rosette growth forms are obvious, although the mature emerged obovate leaves predominantly only have aerenchyma where the petiole and blade initially connect. There are two prominent relatives of sponge plant with similar morphologic features found in North America, frog's bit (Limnobium spongia) and European frog's bit (Hydrocharis morsus-ranae L.). Frog's bit is a native of the Southern United States, however is considered problematic in the Northeastern United States [6], and European frog's bit is also problematic and invasive in the Northeast portion of North America [7]. Limnobium can be differentiated from Hydrocharis by emergent leaves, which European frog's bit only has floating leaves [8]. A diagnostic feature for discerning frog's bit versus sponge plant is the leaf tip; sponge plant has spathulate leaves, while frog's bit has pointed blades.

Past management practices for sponge plant have been aggressive, with eradication as the management objective. Typical means of removal have been mechanical harvesting and herbicide treatment. The primary means of chemical control in the Sacramento-San Joaquin Delta has been diquat dibromide with some limited use of glyphosate [9] [10]. There are minimal data on the efficacy of these two herbicides for sponge plant control and diquat has a low allotment of acres to which it can be applied in the Delta, reducing usefulness in a control 
program [9] [10]. The focus of this research was to investigate the performance of various herbicides in combination with either methylated seed oil or a silicon based adjuvant for control of sponge plant. This research also demonstrates how differing treatment scales aid in evaluating herbicide efficacy for floating plants, and compares plant coverage, using image analysis software and biomass.

\section{Materials and Methods}

\subsection{Initial Herbicide Screen}

Three toxicity experiments were used to assess alternative means to improve control options for sponge plant. Sponge plant used in the bioassays was collected from Sacramento-San Joaquin Delta in California, and shipped for experimentation to, the SePRO Research \& Technology Campus located in Whitakers, NC, U.S.A. The initial experiment was performed in $12 \mathrm{~L}$ aquaria in an indoor laboratory under T8 fluorescent lighting with well-water (average water quality parameters: $\mathrm{pH} 7.5$, Free reactive phosphorus $166 \mu \mathrm{g} \mathrm{L}^{-1}$, Total phosphorus $213 \mu \mathrm{g} \mathrm{L} \mathrm{L}^{-1}$, Alkalinity $133 \mathrm{mg}$ $\mathrm{L}^{-1}$ as $\mathrm{CaCO} 3$, Hardness $87 \mathrm{mg} \mathrm{L}^{-1}$ as $\mathrm{CaCO}_{3}$, Total Kjelahl Nitrogen $1.08 \mathrm{mg} \mathrm{L}^{-1}$, Total Nitrogen $1.56 \mathrm{mg} \mathrm{L}^{-1}$, Conductivity $332 \mu \mathrm{S} \mathrm{cm}^{-1}$ ) and slight aeration in each aquarium. Plants were tested in the seedling stage and allowed to grow until the water's surface was covered before treatments were applied. The following treatments were evaluated using a hand-held foliar sprayer applying a solution of $935 \mathrm{~L} \mathrm{ha}^{-1}$ (100 gallons $\mathrm{acre}^{-1}$ ) with one-percent methylated seed oil (AtmosTM Adjuvant, WinField $^{\circledR}$, Saint Paul, MN): untreated control, $140 \mathrm{~g}$ imazamox ha ${ }^{-1}, 280 \mathrm{~g}$ imazamox ha ${ }^{-1}, 560 \mathrm{~g}$ imazamox ha ${ }^{-1}, 35 \mathrm{~g}$ penoxsulam ha ${ }^{-1}, 70 \mathrm{~g}$ penoxsulam ha ${ }^{-1}, 33 \mathrm{~g}$ carfentrazone-ethyl ha ${ }^{-1}, 66 \mathrm{~g}$ carfentrazone-ethyl ha ${ }^{-1}, 98 \mathrm{~g}_{\text {topramezone ha }}{ }^{-1}, 196 \mathrm{~g}$ topramezone ha ${ }^{-1}, 59 \mathrm{~g}$ florpyrauxifen-benzyl ha ${ }^{-1}, 140 \mathrm{~g}$ imazamox ha ${ }^{-1}$ with $33 \mathrm{~g}$ carfentrazone-ethyl ha ${ }^{-1}$, and $70 \mathrm{~g}$ penoxsulam ha ${ }^{-1}$ with $59 \mathrm{~g}$ florpyrauxifen-benzyl $\mathrm{ha}^{-1}$ (Table 1). The in-water exposures were terminated two days after treatment (DAT) by flushing the $12 \mathrm{~L} 0.8 \mathrm{~m}$ tall cylindrical aquaria simultaneously at $8.3 \mathrm{~L}$ $\mathrm{h}^{-1}$ for six $\mathrm{h}$. Twenty-five days after treatment (25 DAT) fresh weight was measured

Table 1. List of herbicide characteristics sources.

\begin{tabular}{ccccc}
\hline Active Ingredient & Trade name Formulation & $\begin{array}{c}\text { \% Active } \\
\text { Ingredient }\end{array}$ & $\begin{array}{c}\text { Manufacturer } \\
\text { (City, State, website) }\end{array}$ \\
\hline Imazamox & Clearcast $^{\circledR}$ & Water based & 12.1 & $\begin{array}{c}\text { SePRO Corporation, Carmel, } \\
\text { IN, http://www.sepro.com/ }\end{array}$ \\
Penoxsulam & Galleon ${ }^{\circledR}$ SC & SC & 21.7 & $\begin{array}{c}\text { SePRO Corporation, Carmel, } \\
\text { IN, http://www.sepro.com/ }\end{array}$ \\
Carfentrazone-ethyl & Stingray ${ }^{\circledR}$ & EC & 21.3 & $\begin{array}{c}\text { SePRO Corporation, Carmel, } \\
\text { IN, http://www.sepro.com/ }\end{array}$ \\
Topramezone & Oasis ${ }^{\circledR}$ & SC & 29.7 & $\begin{array}{c}\text { SePRO Corporation, Carmel, } \\
\text { IN, http://www.sepro.com/ }\end{array}$ \\
Florpyrauxifen-benzyl & Procellacor ${ }^{\circledR}$ & SC & 26.46 & $\begin{array}{c}\text { SePRO Corporation, Carmel, } \\
\text { IN, http://www.sepro.com/ }\end{array}$ \\
\hline
\end{tabular}


using a laboratory balance with $0.01 \mathrm{~g}$ accuracy. Significant differences were assessed using ANOVA and Tukey's method ( $\alpha=0.05 ; \mathrm{n}=3$; R, 2017, http://www.R-project.org/).

\subsection{Second Toxicity Experiment Evaluating Adjuvants}

In the second trial, the bioassay was conducted in a climate-controlled greenhouse at a larger scale (18.9 $\mathrm{L}$ or five gallon aquaria), using the same well water as used in the indoor experiment. This bioassay focused on the acetolactate synthase (ALS) inhibitors and comparing efficacy of the methylated seed oil and silicon-based adjuvants. Plants were allowed to reach the rosette stage and cover the water's surface before treatments were applied. The treatments were: $70 \mathrm{~g}$ penoxsulam $\mathrm{ha}^{-1}$ in one-percent methylated seed oil (Sun Wet TM, Brewer International, Vero Beach, FL), $280 \mathrm{~g}$ imazamox $\mathrm{ha}^{-1}$ in one-percent methylated seed oil, and $70 \mathrm{~g}$ penoxsulam ha ${ }^{-1}$ with $0.94 \mathrm{~mL}$ silicon based surfactant $\mathrm{L}^{-1}$ (12 fl oz 100 gallons $^{-1}$; SILENERGY TM, Brewer International, Vero Beach, FL). All treatments were applied using a hand-held sprayer at $1870 \mathrm{~L} \mathrm{ha}^{-1}(200$ gallons acre $\left.{ }^{-1}\right)$, and flushed with four volumes of water $(75.6 \mathrm{~L}$ ) at 24 hours after treatment (HAT). Forty-two DAT fresh weight and canopy coverage was measured. Canopy coverage was measured with image analysis software (Canopeo, Division of Agricultural Sciences and natural Resources, OSU App Center, and Soil Physics research group OSU, Tulsa, OK) on a smart phone (iPhone 5๑, Apple, Cupertino, CA) from overhead photographs collected 30.5 $\mathrm{cm}$ above aquaria. The software rapidly measures fractional green canopy cover of photographs and video using color ratios of blue to green, red to green, and an excess green index (2G-R-B) [11]. Significant differences were assessed using an ANOVA $\left(\alpha=0.05 ; \mathrm{n}=3\right.$; Excel $^{\circledR}$ 2016, Microsoft. One Microsoft Way, Redmond, WA).

\subsection{Large Mesocosm Herbicide Evaluation}

The last trial was the largest of the three in scale and conducted in a climate controlled greenhouse in $2000 \mathrm{~L}$ mesocosms with a 1.44 square meter area (15.6 $\mathrm{ft}^{2}$ ). The same well water was used in this experiment as was in the prior experiments. Plants were allowed to reach maturity into the stalked emerged flowering form and completely covered the water's surface before treatments were applied. Treatments were $70 \mathrm{~g}$ penoxsulam $\mathrm{ha}^{-1}$ in one-percent methylated seed oil, and $280 \mathrm{~g}_{\text {imazamox }} \mathrm{ha}^{-1}$ in one-percent methylated seed oil (Sun $\mathrm{Wet}^{\mathrm{TM}}$ ). Treatments were applied using a hand-held sprayer at $1375 \mathrm{~L} \mathrm{ha}^{-1}$ (147 gallons acre-1). Canopy coverage was measured two and four weeks after treatment (WAT), using the same methods in the second trial, in three delineated areas of each mesocosm, with each treatment having one mesocosm. The purpose of this study was to evaluate the efficacy of penoxsulam and imazamox with mature plants at a large controlled scale. Differences of canopy through time were discerned with ANOVA and Tukey's method (R; $\alpha=0.05$ ). 


\section{Results and Discussion}

\subsection{Initial Herbicide Screen}

Results of the small-scale, $12 \mathrm{~L}$ herbicide screen, indicated sponge plant was responsive to treatments of imazamox, penoxsulam, and topramezone, while tolerant to tested treatments of carfentrazone-ethyl and florpyrauxifen-benzyl (Figure 1). There was no significant alteration of efficacy of $140 \mathrm{~g}$ imazamox $\mathrm{ha}^{-1}$ when used in combination with $33 \mathrm{~g}$ carfentrazone-ethyl ha ${ }^{-1}$ nor did $70 \mathrm{~g}$ penoxsulam ha ${ }^{-1}$ differ when used with $59 \mathrm{~g}$ florpyrauxifen-benzyl ha ${ }^{-1}(\alpha=0.05$; $\mathrm{n}=3$ ). A review of the herbicide labels [12] [13] revealed frog's bit, a close relative of sponge plant, is designated as controlled by penoxsulam and imazamox. In general, carfentrazone-ethyl and florpyrauxifen-benzyl are considered more potent on dicots rather than monocots, such as sponge plant. However, these actives were included because they have been found as potent herbicide formulations on other select monocots. For example, florpyrauxifen-benzyl has a unique

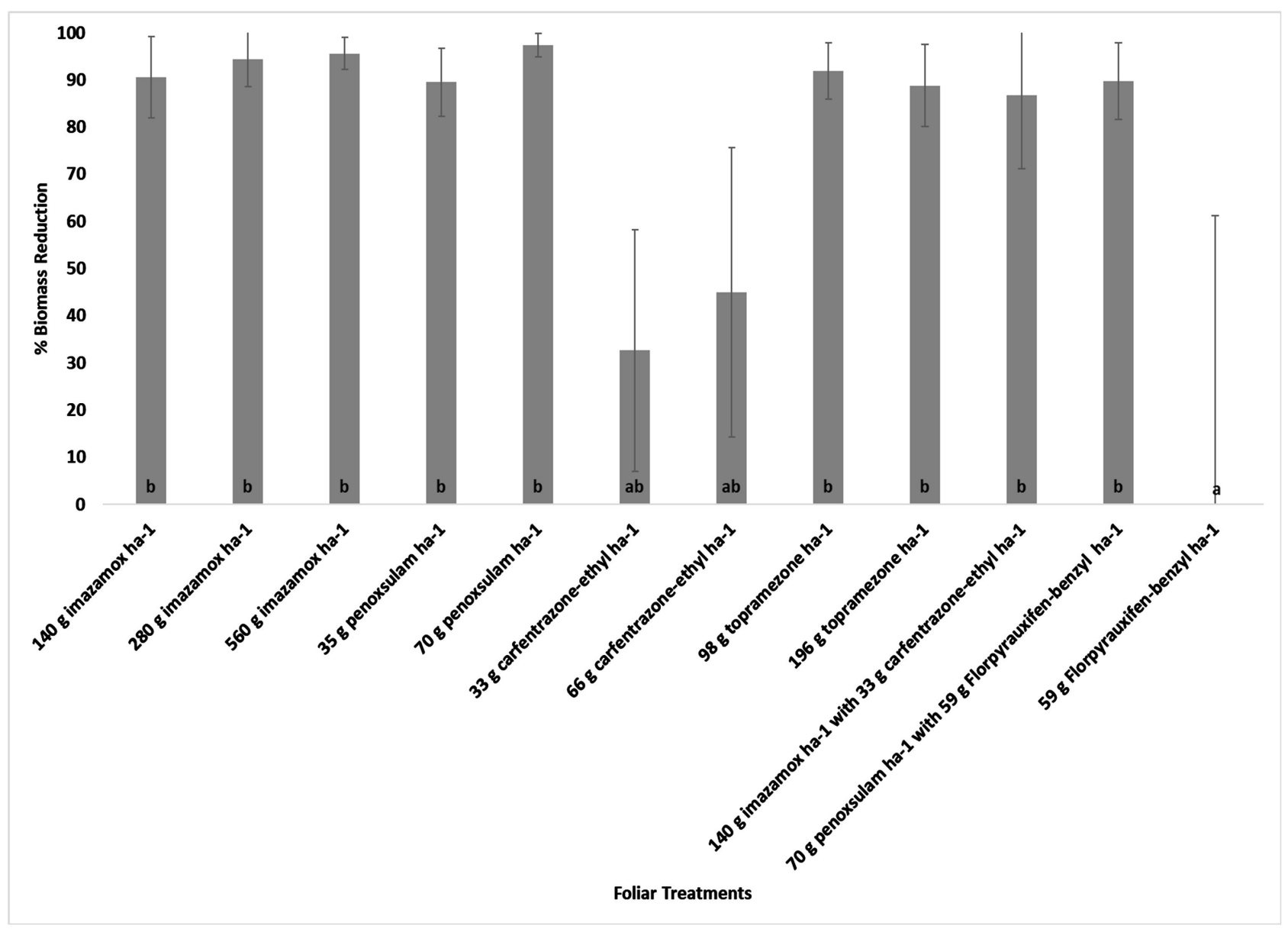

Figure 1. Percent biomass reduction (fresh weight versus untreated controls) of spongeplant 25 DAT with $140 \mathrm{~g}^{\text {imazamox ha }}{ }^{-1}$, $280 \mathrm{~g}$ imazamox ha $\mathrm{h}^{-1}, 560 \mathrm{~g}$ imazamox ha $\mathrm{h}^{-1}, 35 \mathrm{~g}$ penoxsulam ha $\mathrm{h}^{-1}, 70 \mathrm{~g}$ penoxsulam ha $\mathrm{h}^{-1}, 33 \mathrm{~g}$ carfentrazone-ethyl ha-1, $66 \mathrm{~g}$ carfentrazone-ethyl ha ${ }^{-1}, 98 \mathrm{~g}$ topramezone ha ${ }^{-1}, 196 \mathrm{~g}$ topramezone ha $\mathrm{h}^{-1}, 59 \mathrm{~g}$ florpyrauxifen-benzyl ha ${ }^{-1}, 140 \mathrm{~g}$ imazamox ha ${ }^{-1}$ with $33 \mathrm{~g}$ carfentrazone-ethyl ha ${ }^{-1}$, or $70 \mathrm{~g}$ penoxsulam ha $\mathrm{h}^{-1}$ with $59 \mathrm{~g}$ florpyrauxifen-benzyl ha ${ }^{-1}$. All treatments were applied with one-percent MSO. Error bars are \pm one standard deviation $(\mathrm{n}=3)$. Different letters denote significant differences $(\alpha=0.05)$. 
mode of action that allows for control of hydrilla (Hydrilla verticillata) with limited activity on elodea (Elodea canadensis), which are both monocots [14]. Carfentrazone-ethyl has activity for Lemna sp. control, while having only limited impact when used alone on Hydrilla verticillata [15] [16] [17].

\subsection{Second Toxicity Experiment Evaluating Adjuvants}

When the scale was increased to the intermediate $18.9 \mathrm{~L}$ containers, there was not an observed difference in efficacy of penoxsulam at $70 \mathrm{~g} \mathrm{ha}^{-1}$ or imazamox at $280 \mathrm{~g} \mathrm{ha}^{-1}$ in one-percent methylated seed oil for sponge plant control ( $\alpha=0.05$, $\mathrm{n}=3$; Figure 2). There was no measured significant difference in the efficacy of penoxsulam at $70 \mathrm{~g} \mathrm{ha}^{-1}$ with either methylated seed oil or silicon based adjuvant $(\alpha=0.05 ; \mathrm{n}=3)$ using biomass and canopy reductions. However, we hypothesize as time increased there, would have been a difference in the performance, with methylated seed oil surfactant outperforming the silicon-based adjuvant. Evidence to support this hypothesis was visual. At the end of the bioassay, there were actively growing plants in the penoxsulam treatment with the silicon based-adjuvant, while all the plants appeared dead and necrotic in the penoxsulam treatment using the methylated seed oil surfactant. Additionally, the Galleon SC label specifically states "Use of organosilicone surfactants with penoxsulam is not recommended" [12]. The image analysis software yielded comparable results as biomass in this toxicity experiment. Care was needed in removing filamentous algae from the plants before measurement of either biomass or canopy coverage. Submerged algae (planktonic or filamentous) are not detected with the canopy measurement. Field use of the image analysis software should consider the influence floating alga mats, as well as non-target floating plants, can create when

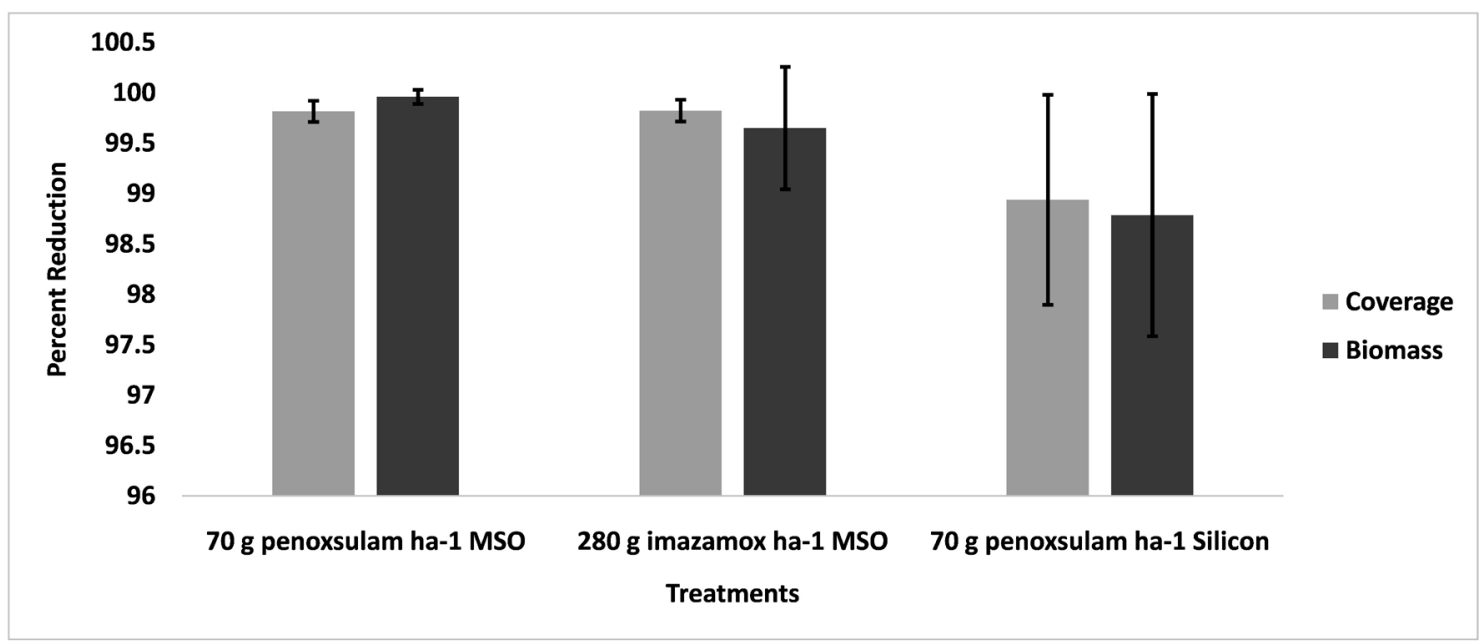

Figure 2. Percent reduction of fresh weight biomass (dark bars) and green coverage (light bars) versus untreated controls of spongeplant 42 DAT with 70 g penoxsulam ha ${ }^{-1}$ in $1 \%$ methylated seed oil, $280 \mathrm{~g}$ imazamox ha $^{-1} \mathrm{MSO}$ in $1 \%$ methylated seed oil, or 70 g penoxsulam ha ${ }^{-1}$ with $0.94 \mathrm{~mL}$ silicon based surfactant $\mathrm{L}^{-1}$. Error bars are \pm one standard deviation $(\mathrm{n}=3)$. Note the $\mathrm{y}$-axis is broken starting at 96 percent reduction $\mathrm{v}$ untreated controls rather than zero. An asterisk denotes significant differences between treatments $(\alpha=0.05)$. No significant differences were discerned. 
measuring canopy coverage. The detection of floating algal mats with the image analysis software indicates potential use of the application for assessing algaecide performance. More research is needed to determine the utility of an endoscope or water proofing function to allow use for measuring submerge vegetation coverage, as the reflection on the surface of the water inhibited detection of submerged foliage or algae.

\subsection{Large Mesocosm Herbicide Evaluation}

In the largest scale experiment $(2,000 \mathrm{~L}$ mesocosms), reduction of canopy was observed with the untreated control and $280 \mathrm{~g}$ imazamox/ha (Figure 3; $\alpha=0.05$; $\mathrm{n}=3$ ). The canopy decline in the untreated control was attributed to Aphidoidea sp. (aphids). More aphids were found on the untreated plants than the $70 \mathrm{~g}$ penoxsulam ha $\mathrm{ha}^{-1}$ and $280 \mathrm{~g}$ imazamox ha ${ }^{-1}$ treated sponge plant, which was accredited to being spatially closer to the aphid source in the greenhouse. The mesocosm that housed the penoxsulam treated plants was physically between the imazamox and untreated control aquaria, however did not have a significant decline in sponge plant coverage pre-treatment to 4 WAT $(\alpha=0.05 ; \mathrm{n}=3$ ). Visually, there was an obvious herbicide effect from the $280 \mathrm{~g}$ imazamox ha ${ }^{-1}$ treated plants, which was measured as significantly different from the pre-treatment coverage as well as untreated plant coverage 4 WAT ( $\alpha=0.05$; $\mathrm{n}=$ 3). Unexpectedly, the $70 \mathrm{~g}$ penoxsulam $\mathrm{ha}^{-1}$ was not effective in the largest scale with well-established and mature sponge plant, while the $280 \mathrm{~g}^{\text {imazamox }} \mathrm{ha}^{-1}$ treatment was effective. At 4 WAT, approximately $10 \%$ of the plants in the $280 \mathrm{~g}$ imazamox $\mathrm{ha}^{-1}$ treated mesocosm appeared to be healthy. We hypothesize these plants did not come in direct contact with the herbicide based on their position in the mesocosm, small statue, and lack of herbicide symptoms (diminutive

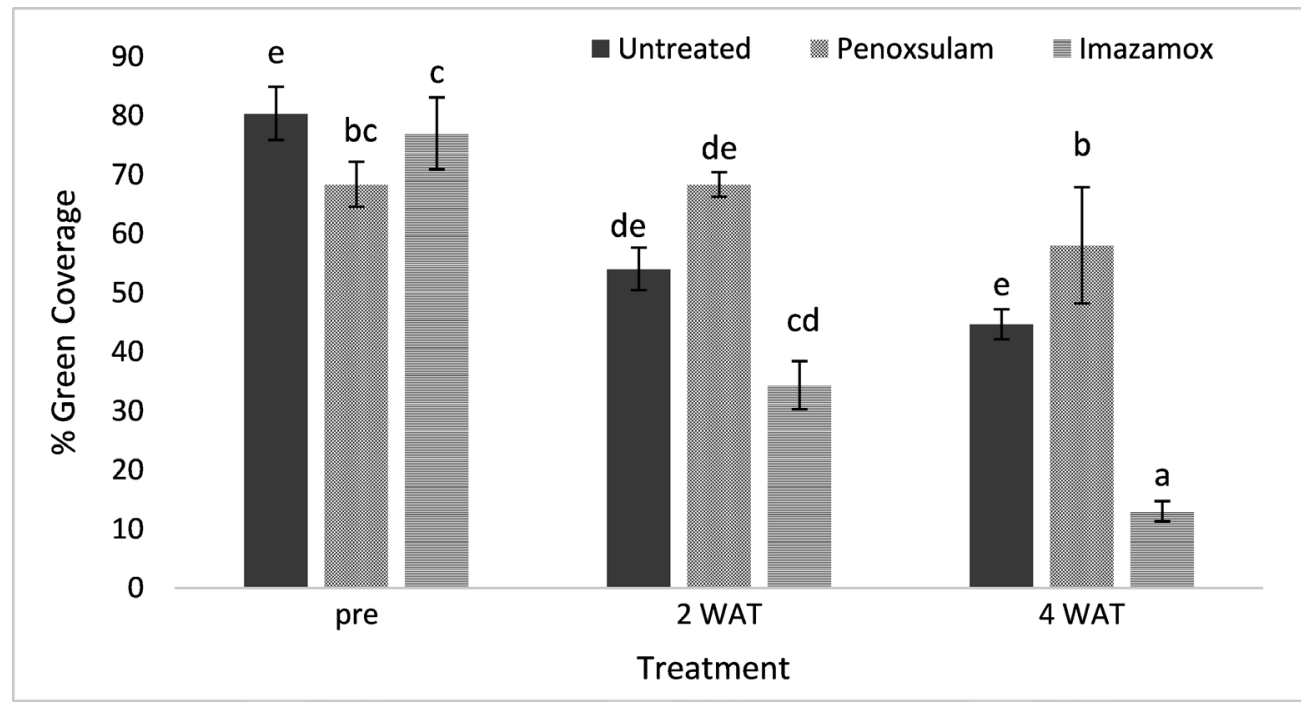

Figure 3. Percent green coverage of spongeplant before treatment, 14, and 28 DAT with $70 \mathrm{~g}$ penoxsulam ha ${ }^{-1}, 280 \mathrm{~g}$ imazamox ha ${ }^{-1} \mathrm{MSO}$, as well as untreated control. Error bars are \pm one standard deviation $(n=3)$. Different letters denote significant differences between treatments $(\alpha=0.05)$. 
foliage or chlorotic meristem). These plants that assumed "escaped" treatment rapidly recolonized the mesocosm to an estimated 50 percent by nine WAT. Management practices using a foliar imazamox treatment will likely require a follow up spot treatment after four weeks to prevent recolonization if sponge plant escape foliar spray.

\section{Conclusion}

Overall, $280 \mathrm{~g}$ imazamox $\mathrm{ha}^{-1}$ (with one-percent methylated seed oil surfactant) was found as a potent solution for all different growth stages of sponge plant, and $70 \mathrm{~g}$ penoxsulam $\mathrm{ha}^{-1}$ as an alternative for control of sponge plant in the seedling and rosette growth stage. Mesocosm testing indicated treatment sites should be inspected every four weeks to treat any sponge plant missed by prior applications. This research is critical to guiding improved sponge plant control and highly applicable to water resource managers, due to the marginal effectiveness of current management practices yielding continued spread of this invasive species.

\section{Acknowledgements}

The authors thank SePRO Corporation for funding this research, as well as WinField ${ }^{\circledR}$ and Brewer International for donation of adjuvants used in this research.

\section{References}

[1] Cook, C.D.K. (1985) Range Extensions of Aquatic Vascular Plant Species. Journal of Aquatic Plant Management, 23, 1-6. https://www.apms.org/japm/vol23/v23p1.pdf

[2] US Department of Agriculture Agricultural Research Service, USDA-ARS (2016) US National Plant Germplasm System, Online Database. https://npgsweb.ars-grin.gov/gringlobal/search.aspx

[3] California Department of Food and Agriculture, CDFA (2010) A New Invader South American Sponge Plant: Worse than Water Hyacinth?. https://www.cdfa.ca.gov/plant/ipc/hydrilla/sos/sos_flyer.pdf

[4] Anderson, L. (2011) Sponge plant: A New Aquatic Weed Threat in the Delta. Cal-IPC News, 19, 4-5.

[5] US Department of Agriculture and the California Department of Boating and Waterways USDA and CDBW (2012) Water Hyacinth Control Program Biological Assessment, 274 http://www.dbw.ca.gov/pages/28702/files/WHCP-Biological_Assessment-121025.pdf

[6] Mackenzie, K.K. (1920) The Records for Limnobium spongia in the Northern United States. Torreya, 22,102-104.

http://www.jstor.org/stable/40596336?seq=1\#page_scan_tab_contents

[7] Catling, P.M. and Dore, W.G. (1982) Status and Identification of Hydrocharis Morsus-Ranae and Limnobium Spongia in Northeastern North America. Rhodora, 84, 523-545

[8] Cook, C.D.K. and Urmi-König, K. (1983) A Revision of the Genus Limnobium including Hydromystria (Hydrocharitaceae). Aquatic Botany, 17, 1-27. 
https://doi.org/10.1016/0304-3770(83)90015-3

[9] California Department of Parks and Recreation, CDPR (2013) Water Hyacinth and Sponge Plant Control Programs: Water Hyacinth Control Program and Sponge Plant Control Program Aquatic Pesticide Application Plan. 15 p.

https://dbw.parks.ca.gov/pages/28702/files/WHCP\%20SCP\%20Aquatic\%20Pesticid e\%20Application\%20Plan\%202013.pdf

[10] Madsen, J. (2016) Personal Communication. 14 September 2016.

[11] Patrignani, A. and Ochsner, T.E. (2015) Canopeo: A Powerful New Tool for Measuring Fractional Green Canopy Cover. Agronomy Journal, 107, 2312-2320.

https://doi.org/10.2134/agronj15.0150

[12] SePRO (2017) Galleon ${ }^{\circledR}$ SC Aquatic Herbicide Specimen Label. http://www.sepro.com/documents/Galleon_Label.pdf

[13] SePRO (2017) Clearcast ${ }^{\circledR}$ Aquatic Herbicide Specimen Label. http://www.sepro.com/documents/Clearcast_Label.pdf

[14] Netherland, M. and Richardson, R.J. (2015) Evaluating Sensitivity of Five Aquatic Plants to a Novel Arylpicolinate Herbicide Utilizing an Organization for Economic Cooperation and Development. Weed Science, 64, 181-190. https://doi.org/10.1614/WS-D-15-00092.1

[15] Getsinger, K.D., Poovey, A.G., Glomski, L., Slade, J.G., and Richardson, R.J. (2011) Utilization of Herbicide Concentration/Exposure Time Relationships for Controlling Submersed Invasive Plants on Lake Gaston, Virginia/North Carolina. US Army Corp Engineers, ERDC/EL TR-11-5, 16 p.

[16] Masser, M.P., Murphy, T.R., and Shelton, J.L. (2013) Aquatic Weed Management: Herbicides. Southern Regional Aquaculture Center, Publication No. 361.

http://aquaculture.ca.uky.edu/sites/aquaculture.ca.uky.edu/files/srac_361_aquatic_ weed_management_herbicides.pdf

[17] SePRO (2017) Stingray ${ }^{\circledR}$ Aquatic Herbicide Specimen Label. http://www.sepro.com/documents/Stingray_Label.pdf 